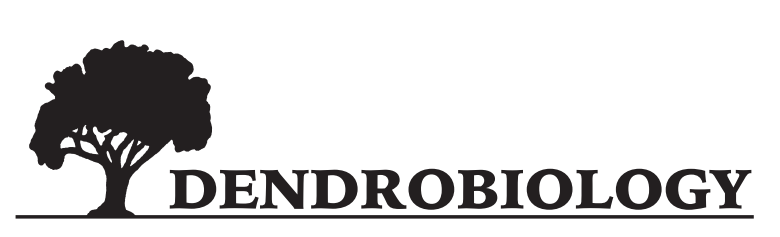

2017, vol. 78, 146-156

http://dx.doi.org/10.12657/denbio.078.014

\author{
Radostaw Jagietło ${ }^{1}$ Edward Baraniak ${ }^{2}$, Piotr Karolewski ${ }^{1}$, \\ Piotr Łakomy ${ }^{3}$, Jolanta Behnke-Borowczyk ${ }^{3}$, Urszula Walczak ${ }^{4}$, \\ Marian J. Giertych ${ }^{5}$
}

\title{
Ecophysiological aspects of the interaction between Cameraria ohridella and Guignardia aesculi on Aesculus hippocastanum
}

\author{
Received: 19 May 2017; Accepted: 21 August 2017
}

\begin{abstract}
Popular in the urban environment is the horse chestnut, Aesculus hippocastanum which is suffering mainly due to the feeding of the horse chestnut leaf miner (Cameraria ohridella). The harmfulness of this pest is well recognized. Not much attention was put in discovering the interaction of this insect with the fungal pathogen Guignardia aesuli, the agent of leaf blotch. Host plant mediation in this particular insect-plant pathogen interaction is crucial for understanding the complexity of the horse chestnut's current and future situation. Recognising the response of the host plant for separated and simultaneous colonisation by insect and fungus was the aim of this study. Leaf damage dynamics and phenolic compounds content (total soluble phenolic compounds - TPh, and condensed tannins - CT), and stem volume increment (SVI) of the horse chestnut saplings was considered and their relationship identified. The main hypothesis was that insect feeding and fungal infection when separated elicit a similar pattern in defence response of the host but this defence response is different when they both coexist on the same plant. Basing on crown projection area photographs sequence, foliage damage dynamics was assessed (Richard's growth model) and protocol developed. Measurements of stem volume were performed sequentially to indicate potential growth response. Through this study, it was identified that the content of phenolic compounds in leaves was higher when both pests colonized saplings in comparison with those where saplings were infested by one biotic factor. It is also documented that foliage damage dynamics was higher when only the fungal pathogen attacked plants than when it was infected by both pests. A trade-off was identified between growth and secondary metabolism. Leaf damage affected stem volume increment only in the late summer, when a high level of defoliation was observed. Simultaneous infestation by fungal and insect agents made unfavourable conditions rather for the former. How this interaction affects the latter is not covered by our results and still remains undiscovered.
\end{abstract}

Keywords: plant growth, foliage damage, leaf blotch, leaf miner, plant defence

Addresses: ${ }^{1}$ Institute of Dendrology, Polish Academy of Sciences, Parkowa 5, 62-035 Kórnik, Poland, e-mail: rjagiello@man.poznan.pl; pkarolew@man.poznan.pl

${ }^{2}$ Adam Mickiewicz University, Faculty of Biology, Department of Systematic Zoology, Umultowska 89, 61614 Poznań, e-mail: baraniak@amu.edu.pl

${ }^{3}$ Poznan University of Life Sciences, Faculty of Forestry, Department of Forest Pathology, Wojska

Polskiego 71 C, 60-625, Poznań, e-mail: plakomy@up.poznan.pl; jbehnke@up.poznan.pl

${ }^{4}$ Adam Mickiewicz University, Faculty of Biology, Department of Systematic Zoology, Umultowska 89, 61-

614 Poznań, Poland, e-mail: urszulaw@amu.edu.pl

${ }^{5}$ Institute of Dendrology, Polish Academy of Sciences, Parkowa 5, 62-035 Kórnik, Poland

University of Zielona Góra, Faculty of Biological Sciences, Prof. Z. Szafrana 1, 65-516 Zielona Góra, Poland, e-mail: giertych@man.poznan.pl 


\section{Introduction}

The host plant can serve as an essential source for survival simultaneously of more than one consumer. This phenomenon is known as tripartite plant-mediated interaction between plant pathogens and arthropods (Stout et al., 2006). The way plants recognise and respond depends on the type of consumer and their strategy for accessing their food (Kessler $\&$ Baldwin, 2002). Interaction between both the insect feeding mode (chewing/phloem feeding) and pathogen trophic strategy (bio-, necro- and hemibiotrophic) results in different mechanisms of plant defence (Lazebnik et al., 2014). Chemical defence in plants, constitutive as well as induced, can influence intruders directly (by lowering quality of sustenance) or indirectly (by attraction of other organisms that could protect the plant) and plenty of biochemical compounds were found to play this role (Mithöfer \& Boland, 2012). Two pathways, involving jasmonic acid and salicylic acid have been established as primary in defence induction (Thomma et al., 2001). However, interactions between defence and growth signalling also alters plant growth (Huot et al., 2014). Plant investment in defence is carbon-costly (Karolewski \& Jagodziński, 2013) and as a consequence, the potentially obtained resistance could decrease plant fitness (Strauss et al., 2002). Nevertheless, secondary metabolites serve auxiliary roles and also support the primary metabolism of plants (Neilson et al., 2013).

The sequence of colonisation and spatial and temporal diversity by different attackers play important roles in differentiating the food quality for a particular consumer (Stout et al., 2006). The horse chestnut leaf miner (HCLM, Cameraria ohridella Deschka and Dimić; Lepidoptera: Gracillariidae) and the fungal pathogen Guignardia aesculi (Peck) V.B. Stewart (synonym name: Phyllosticta paviae Desm., Ascomycota: Phyllostictaceae; Index Fungorum database), the agent of leaf blotch disease, are different in spatial and temporal distribution on their host, Aesculus hippocastanum $\mathrm{L}$. The former occupies the palisade mesophyll while the latter the whole blade. Hence, fungi may also colonise tissue which was previously occupied by insects. Temporally, HCLM occurs earlier on leaves (Tomiczek \& Krehan, 1998) than G. aesculi, because the former finds the host actively while the latter passively by anemochory and needs more time to settle in the leaves (Hudson, 1987).

Horse chestnut (A. hippocastanum) is a very popular tree species in the urban environment. Hence, without doubt, rapid invasion of the HCLM in the European species (Augustin et al., 2009), as described by Deschka \& Dimić (1986), is the phenomenon being investigated for over 30 years. The previously mentioned insect achieved spectacular ecological success and there is still a lack of versatile biological methods to deal with the problem of year on year premature defoliation of the horse chestnut trees. To date, plenty of studies aimed to recognise the clear interaction between the insect and host tree, including growth and flowering disruption (Franiel et al., 2014), seed quality reduction (Thalmann et al., 2003), limitation in photosynthesis (Percival et al., 2011), and changes in radial increment (Bednarz \& Scheffler, 2008). To date the fungus, G. aesculi was treated very narrowly (Pastirčáková et al., 2009), probably because it has less of an influence on general appearance of the horse chestnut trees. The interaction between insect and fungus in this particular case is treated marginally in the literature (Gilbert et al., 2003; Bhatti et al., 2013) and this gap should be addressed, as it could complete the knowledge about the pest's population dynamics and the ecophysiological aspects of the host plant. In this study, infestation of the insect and infection of fungal pathogen was employed to recognise the response of $A$. hippocastanum saplings to pest colonisation. The study aimed to account for how occupation by organisms with different manners of food acquisition singly and by interaction influenced the defence metabolism expressed in the content of secondary metabolites in leaves of A. hippocastanum. Through this study, an attempt to answer the question of to what extent the costs of secondary metabolisms or/and carbon source limitations by leave damage can influence plant increment. A novel method for assessing the amount of foliage damage is introduced allowing for accurate quantification dynamics of this process on the crown projection. In this study, the three following hypotheses were tested: (i) insect feeding and fungal infection when separated have similar patterns in defence response of the host but different when coexisting on the same plant, hence (ii) foliage damage dynamics are different in these arrangements and (iii) aboveground plant woody tissue increment is decreased when foliage damage and content of defence metabolites is on a higher level.

\section{Materials and methods}

\section{Experimental design}

The experimental plot was established in spring of 2014 in an experimental field of the Institute of Dendrology, Poland (52 $\left.14^{\prime} 40.29^{\prime \prime} \mathrm{N} 17^{\circ} 6^{\prime} 10.92 ” E\right)$, where 120 three-year-old horse chestnut saplings were planted and left for acclimatisation for one season without any treatment. Plants were exposed to full sun. The same year, the leaves from neighbouring avenues of horse chestnut (collected after leaf fall from leaf litter and stored outdoor in rasp bags during the winter) were put in an experimental 
field in early spring. A satisfying amount of colonisation of saplings by $C$. ohridella and G. aesculi was observed during the 2014 vegetative season. Then, in the spring of 2015 , leaves from the leaf litter were collected from this same avenue again and put in an experimental plot in spring of 2015.

The impact of four different management treatments was assessed: the application of insecticide (I), fungicide $(\mathrm{F})$, a combination of both (F\&I) and a control (C) which received no treatment. Solutions of two fungicides - Gwarant 500SC (chlorothalonil) at a concentration of $0.8 \mathrm{mg} \cdot \mathrm{mL}^{-1}$ and Penncozeb 80WP (mancozeb, combination of two other dithiocarbamates: maneb and zineb) at a concentration of $3 \mathrm{mg} \cdot \mathrm{mL}^{-1}$ were used in turn, and against the insect Dimilin 480SC (diflubenzuron) at a concentration of $0.5 \mathrm{mg} \cdot \mathrm{mL}^{-1}$. The leaves of all plants from established experimental variants were sprayed in two week intervals (first on the $18^{\text {th }}$ May, last on the $16^{\text {th }}$ July 2015). Special curtains were installed on experimental plots and unfolded during pesticide treatment between all subplots to prevent spraying plants from the neighbour - a different variant.

\section{Foliage damage assessment}

The dynamics of foliage damage on 36 saplings (9 from each treatment) was measured from the $3^{\text {rd }}$ of June to the $24^{\text {th }}$ of September. For this purpose, photographs from above the plants were taken to provide an image of the crown projection area (CPA). Overhead photographs of saplings were taken with a digital camera equipped with a wide-angle lens (Nikon 1 V2, 1 Nikkor VR 10-30mm F3.5-5.6) in two week intervals. The camera was installed on a tripod stand (Fotomate VT-680-222R EX) with an additional, smaller stand (Noga CineArm DG) with ball heads and an extension tube. This allowed the camera to be set up directly above the centre of the photographed plant at the appropriate height. Wooden slats with marked lengths were laid on the ground to obtain the correct proportions for the images. The wooden slats and the camera were levelled with the aid of a round spirit level and stabilised before the images were taken. The white, cotton material was used as a background to help distinguish between the crown area and ground level plants. A detailed procedure is provided in supplementary material.

Identifying the extent of foliage damage was dependent on the ability to distinguish the healthy and damaged areas from the background of the image. The pixel classification method based on colour in WinFolia Pro 2013 (Regent Instruments Inc.) software was used, because it was found to be the most suited for the study. From the first image, sum of the healthy and damaged (if occurred) areas were used as estimates of initial CPA (iCPA) of sapling.
Following this, healthy areas from subsequent images were used for calculation of the damaged crown projection area (dCPA) as the difference between the initial CPA and area of healthy tissue visible on CPA (hCPA) at a particular date.

\section{Foliage damage dynamics}

Data obtained from image analyses were used for assessing the dynamics of foliage damage during the aboveground vegetative season. The beginning of the vegetative season was established as a date of full leaf development (FLD) and the end of the season was established as the date of full defoliation or natural leaf fall (leaf abscission, LA). These dates were assessed for each sapling separately. For this purpose, observations from day to day were carried out during leaf development and time of leaf fall. Having healthy areas of CPA on particular dates meant that a growth function could be used for approximation of damaged crown projection area (dCPA). We employed a sigmoidal growth model proposed by Richards (1959):

$$
\mathrm{dCPA}=\mathrm{iCPA}\left(1+\mathrm{be}^{-\mathrm{kt}}\right)^{1 /(1-\mathrm{m})} ; \mathrm{m}>1, \mathrm{~b}>1, \mathrm{k}>0
$$

where $\mathrm{m}, \mathrm{b}$, and $\mathrm{k}$ are constant parameters, $\mathrm{t}$ is time (days from FLD) and e is Euler's number. We applied Newton's iterative method for estimating the parameters. Goodness of fit evaluation was made and root mean square error was used for this purpose. Then first (dCPA') and the second (dCPA") derivative of Richards function was calculated as follows (Gregorczyk, 1998):

$$
\begin{gathered}
\mathrm{dCPA}^{\prime}=\frac{\mathrm{iCPAbk}}{(\mathrm{m}-1) \mathrm{e}^{-\mathrm{kt}}\left(1+\mathrm{be}^{-\mathrm{kt}}\right)^{\mathrm{m} /(1-\mathrm{m})}} \\
\mathrm{dCPA}^{\prime \prime}=\left[\frac{\mathrm{iCPAbk} \mathrm{e}^{-\mathrm{kt}}}{(\mathrm{m}-1)^{2}\left(\mathrm{~b}+\mathrm{e}^{\mathrm{kt}}\right)}\left(1+\mathrm{be}^{-\mathrm{kt}}\right)^{\mathrm{m} /(1-\mathrm{m})}\right] \\
{\left[\mathrm{b}+(1-\mathrm{m}) \mathrm{e}^{\mathrm{kt}}\right]}
\end{gathered}
$$

From the first derivative values of relative damage rate (RDR), the day when this value was achieved (RDRday) could be obtain by finding the point of horizontal asymptote. In a similar manner, the maximum damage acceleration (maxDAcc) may be calculated from second derivative. Detailed description of the Richards growth function interpretation is contained in Gregorczyk (1998).

\section{Stem volume increment}

The stem volume of 60 saplings was measured (15 from each treatment), including assessment of all trees with leaf damage dynamics. For this purpose, every stem was divided to four sections, with borders 
on visible annual height increments and lengths of sections measured $( \pm 1 \mathrm{~cm})$. Then, in the middle of each section, a diameter was measured in two perpendicular directions $( \pm 0.1 \mathrm{~mm})$ with calliper and mean diameter calculated. The volume of each section was calculated:

$$
\mathrm{V}_{\mathrm{i}}=\mathrm{L}_{\mathrm{i}} \frac{\mathrm{D}_{\mathrm{i}}^{2}}{400}
$$

where $V_{i}$ is volume of section $i, L$ is length of section and $\mathrm{D}$ is mean diameter on $1 / 2$ of $\mathrm{L}$. From the sum of sections volume, stem volume $\left(\mathrm{V}_{\mathrm{s}}\right)$ was calculated:

$$
\mathrm{V}_{\mathrm{S}}=\sum_{\mathrm{i}}^{\mathrm{n}} \mathrm{V}_{\mathrm{i}}
$$

where $\mathrm{n}$ is number of sections. Three measurements were made during the investigation: in early spring (iSV), at the end of July and in October, after leaf fall. For the last two measurements, one additional section was added, as saplings grown for height. Based on this data, three values of increment were calculated: two periodical stem volume increments $\left(\mathrm{pSVI}_{\mathrm{V}-\mathrm{VII}}\right.$ and $\mathrm{pSVI} \mathrm{V}_{\mathrm{VII-LA}}$ for first and second period respectively) and an annual stem volume increment (aSVI).

\section{Molecular analyses}

The pieces of leaves with disease symptoms was collected and transferred to laboratory. Each sample was surface sterilized in sodium hypochlorite ( $2 \%$ active chlorine) for 15-30 s and rinsed three times in sterile, demineralized water for $>10 \mathrm{~s}$. The pieces were dried between paper towels and frozen. Next frozen pieces of leaves were pounded in mortar. Total genomic DNA was extracted from pounded tissue using the Bead-Beat Micro Gravity kit (A\&A BIOTECHNOLOGY, Gdynia). PCR amplification of the ITS $1 / 2$ rDNA was done with DNA diluted (10-2) in deionized water. Primers used were ITS1-F (5'CTT GGT CAT TTA GAG GAA GTA A) (Gardes \& Bruns, 1993) as well as ITS4 (5' TCCTCCGCTTATTGATATGC 3') (White et al., 1990). Each $25 \mu \mathrm{l}$ PCR mixture consisted of $0.2 \mu \mathrm{mol} \mathrm{L}-1$ of each primer, $0.25 \mathrm{U}$ of Taq polymerase (MBI Fermentas, St. Leon-Rot, Germany), buffer (10 mmol L-1 Tris-HCl pH 8.8, $50 \mathrm{mmol} \mathrm{L-1} \mathrm{KCl,}$ $0.08 \%$ Nonidet P-40, $0.1 \mathrm{mg}$ ml-1 BSA, $1.5 \mathrm{mmol} \mathrm{L}-1$ $\mathrm{MgCl} 2$ ), $0.2 \mathrm{mmol} \mathrm{L}-1$ deoxyribonucleoside triphosphates (dNTPs) and $2 \mu \mathrm{l}$ of DNA. PCR conditions included an initial denaturation step at $94^{\circ} \mathrm{C}$ for 10 min, followed by 30 cycles of $94^{\circ} \mathrm{C}$ for $30 \mathrm{~s}, 42^{\circ} \mathrm{C}$ for 1 $\min$ and $72^{\circ} \mathrm{C}$ for $2 \mathrm{~min}$. This was followed by a final extension of $72^{\circ} \mathrm{C}$ for $10 \mathrm{~min}$. The PCR products were checked by electrophoresis of $5 \mathrm{ml}$ of the product in a
$1 \%$ agarose gel containing ethidium bromide $(0.5 \mathrm{mg}$ ml_1). PCR products were purified using the MinElute PCR purification kit (Qiagen, Crawley, UK). The amplified fragments were sequenced at the Centre of DNA Studies in Poznań, Poland. Sequences were identified by comparison with reference sequences in the NCBI GenBank.

\section{Chemical analyses}

Sun exposed leaves were collected for chemical analyses at the turn of June and July from 36 saplings (nine for each experimental variant), excluding saplings destined for leaf damage and stem volume increment measurements. Tissue with necrosis caused by pests was dissected and the healthy part taken for analysis. Defence compounds, i.e. condensed tannins (CT) and total soluble phenolic (TPh) were measured in dried $\left(40{ }^{\circ} \mathrm{C}\right.$ for $\mathrm{CT}$, and $65^{\circ} \mathrm{C}$ for $\mathrm{TPh}$, respectively) leaf tissue powdered in a Mikro-Feinmühle-Culatti mill (IKA Labortechnik Staufen, Germany). After extraction with absolute methanol, CT was determined by a colorimetric method, using a colour reaction with vanillin in an acid medium (Price et al., 1978). Readings of absorption were taken at $\lambda=500$ $\mathrm{nm}$, while results were expressed as $\mathrm{mM}$ catechin $\mathrm{g}^{-1}$ dry matter (d.m.). Content of TPh was measured according to Johnson and Schaal (1957), as modified by Singleton \& Rossi (1965). Thus, it was determined using Folin Ciocalteu's Phenol Reagent (Sigma F 9252) at $\lambda=660 \mathrm{~nm}$, and results were expressed as $\mathrm{mM}$ chlorogenic acid $\mathrm{g}^{-1}$ d.m.

\section{Statistical analyses}

A two-way mixed ANOVA model (PROC MIXED) was used to compare pSVI from different sapling treatments in different increment periods. Experimental treatment, increment period and interaction of these effects were considered as fixed factors and the sapling as a random factor nested within the experimental treatment. The one-way ANOVA model (PROC MIXED) was used to compare data (aSVI, RDRday, TPh and CT) and one-way ANCOVA model (PROC MIXED, RDR and maxDAcc) from different sapling treatments and initial CPA were considered as covariate. Forward stepwise analysis was employed to find variables explaining aSVI and pSVI. Variables obtained during investigation were put into a model, i.e. FLD, CPA, RDR, RDRday, maxDAcc, iSV and the $p$ value of independent variable significance in the model was used as a stopping rule $(p=0.25)$. Fitness of obtained models was expressed with the coefficient of determination $\left(\mathrm{R}^{2}\right)$ and Akaike information criterion (AIC). All calculations and statistical analyses were conducted using JMP Pro 13 software (SAS Institute Inc.). 


\section{Results}

\section{Field observations}

Full leaf development (FLD) varied between the $5^{\text {th }}$ and $18^{\text {th }}$ May. Fungicides restrained pathogen development, but did not preserve the leaves totally against it and symptoms of fungal infection were observed also on trees treated with fungicide. On the other hand, no mine of HCLM was indicated on saplings treated with insecticide. Leaf abscission (LA) occurred naturally or because of full defoliation by biotic agents and it was observed between $14^{\text {th }}$ September and $1^{\text {st }}$ October. Finally, the difference between time of LA and FLD was from 125 to 149 days and was longest for saplings from the F\&I variant (Fig. 1).

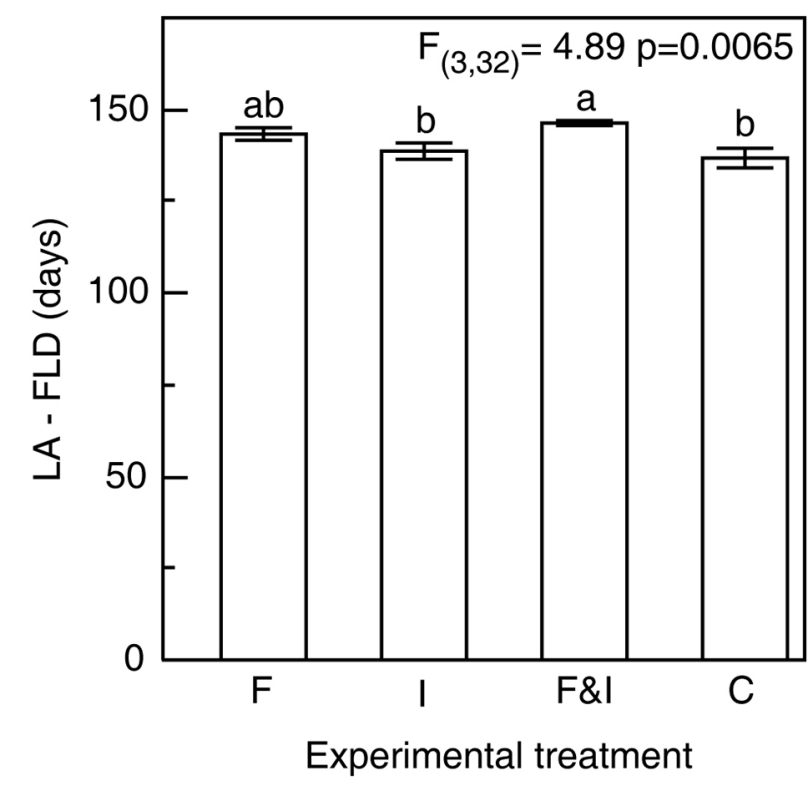

Fig 1. Mean, standard error and ANOVA results for duration of leaves (expressed as difference between day of leaf abscission and full leaf development) of saplings from experimental treatments ( $\mathrm{F}$ - fungicide, $\mathrm{I}$ - insecticide, F\&I - fungicide and insecticide, $\mathrm{C}$ - left without treatment). Means not connected by the same letter are significantly different (Tukey HSD)

\section{Volume increment}

Annual stem volume increment (aSVI) revealed slight differences between treatments applied in the study. Only the control variant, where both biotic factors were not restricted, indicated statistically lower aSVI compared with the saplings treated with fungicide (Fig. 2). It was observed that a great part of SVI took place in the first period (Fig. 3), i.e. from May to the end of July and that the growth trend from the first period was similar to the annual

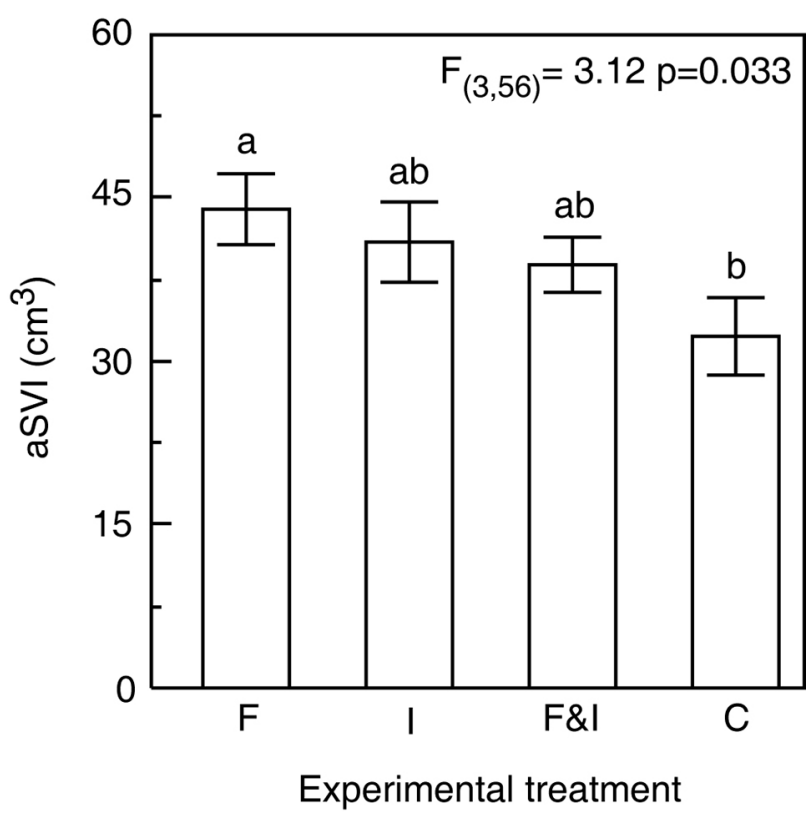

Fig 2. Mean, standard error and ANOVA results for annual stem volume increment (aSVI) of saplings from experimental treatments (description like in previous Figure). Means not connected by the same letter are significantly different (Tukey HSD)

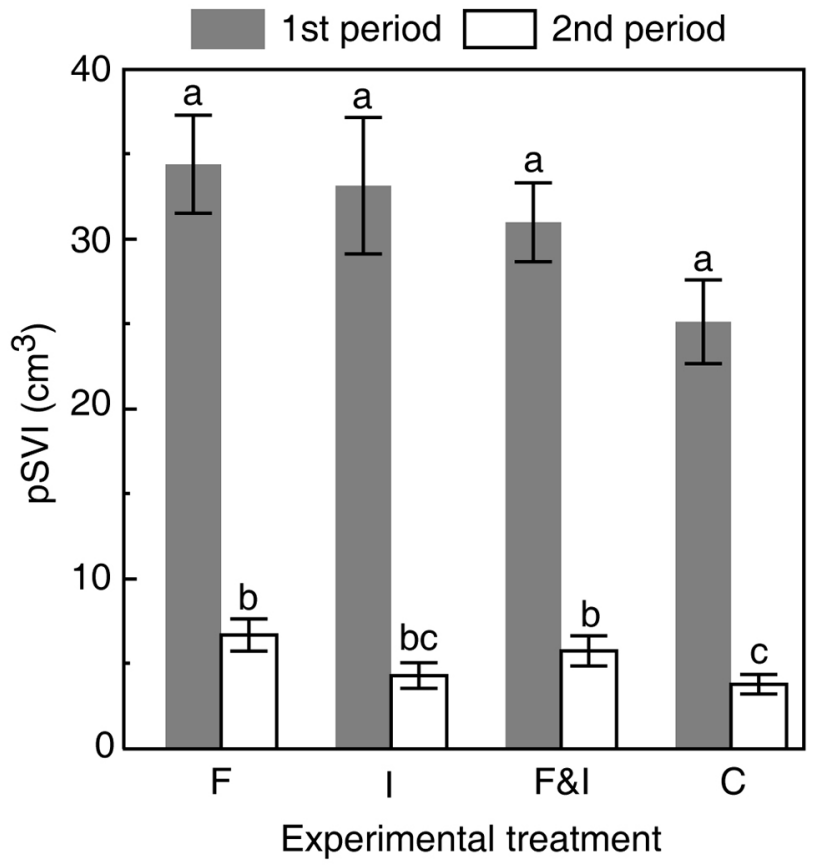

$\begin{array}{lll}\text { Treatment }(T) & F_{(3,56)}=5.00 & p=0.0038 \\ \text { Period }(P) & F_{(1,56)}=481.43 & p<0.0001 \\ \text { Tx P } & F_{(3,56)}=3.34 & p=0.0256\end{array}$

Fig 3. Mean and standard error of periodic stem volume increment (pSVI) of saplings from experimental treatments (description like in Figure 1). Means not connected by the same letter are significantly different (Tukey HSD) 
increment. A relatively small amount of woody tissue was built into stems during the second period, from the beginning of August to the LA. Only the second period increment showed statistically significant differences between different treatment regimes.

\section{Foliage damage dynamics}

Initial CPA was similar between saplings from experimental variants $\left(\mathrm{F}_{(3,32)}=1.07, \mathrm{p}=0.3745\right)$, and variability of this feature was equal to $0.055 \mathrm{~m}^{2}$ (standard deviation) and $22.6 \%$ (coefficient of variation). Root mean square error of Richards growth model was significantly higher for $\mathrm{F}$ and $\mathrm{F} \& \mathrm{I}$ variants (0.0231 and 0.0224 respectively) than $\mathrm{C}$ and I $(0.0104$ and 0.0093 respectively $)\left(\mathrm{F}_{3,32}=7.54, \mathrm{p}=0.0006\right.$, Tukey HSD). That was probably because the last point for the former two variants, indicating day of full defoliation occurred suddenly due to a slight frost. The value of RDR was delayed in vegetative season in variants F and F\&I in comparison with C and I (Fig. 4). Simultaneously, RDR achieved higher value for these variants, (Fig. 5a) as well as maximal damage acceleration (maxDAcc, Fig. 5b), but was slightly lower for $\mathrm{C}$. In effect, leaf damage dynamic was more than two times higher on saplings from $\mathrm{C}$ and I variants in comparison with the other two variants. Richards growth model indicators was affected by natural defoliation phenomenon, especially when we take into

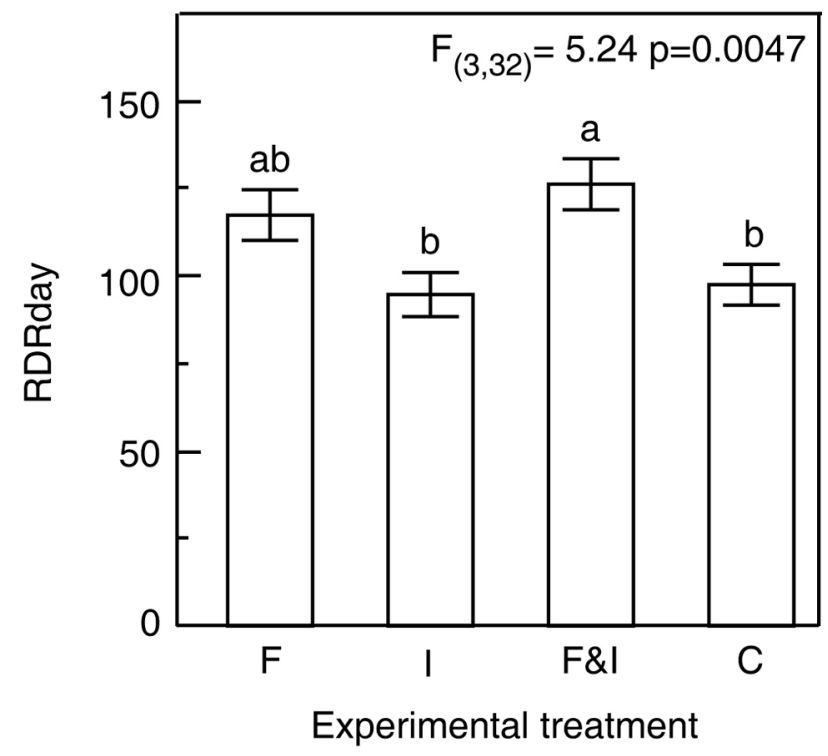

Fig 4. Mean, standard error and ANOVA results for vegetation day, when relative damage rate (RDR) was achieved in growth model on saplings from experimental treatments (description like in Figure 1). Means not connected by the same letter are significantly different (Tukey HSD)

consideration, that day when RDR of saplings from variant $F$ and $F \& I$ was achieved after 120 days. Leaf damage dynamic observed on saplings from the control variant, where both biotic factors coexisted, was
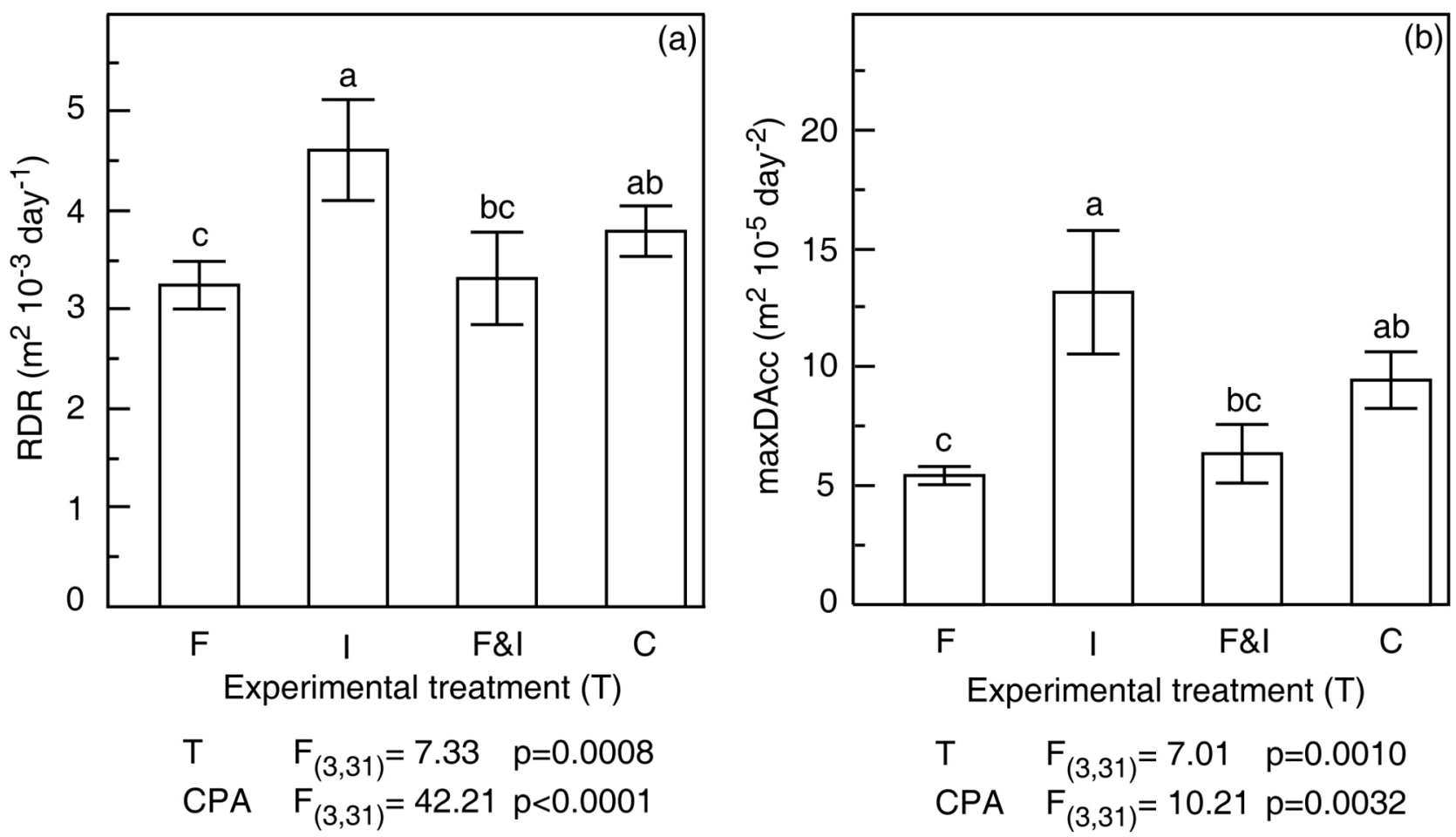

Fig 5. Mean, standard error and ANCOVA (covariate: CPA) results for relative damage rate (RDR, CPA area per day) and maximum damage acceleration (maxDAcc, CPA area per day2) values on saplings from experimental treatments (description like in Figure 1). Means not connected by the same letter are significantly different (Tukey HSD) 

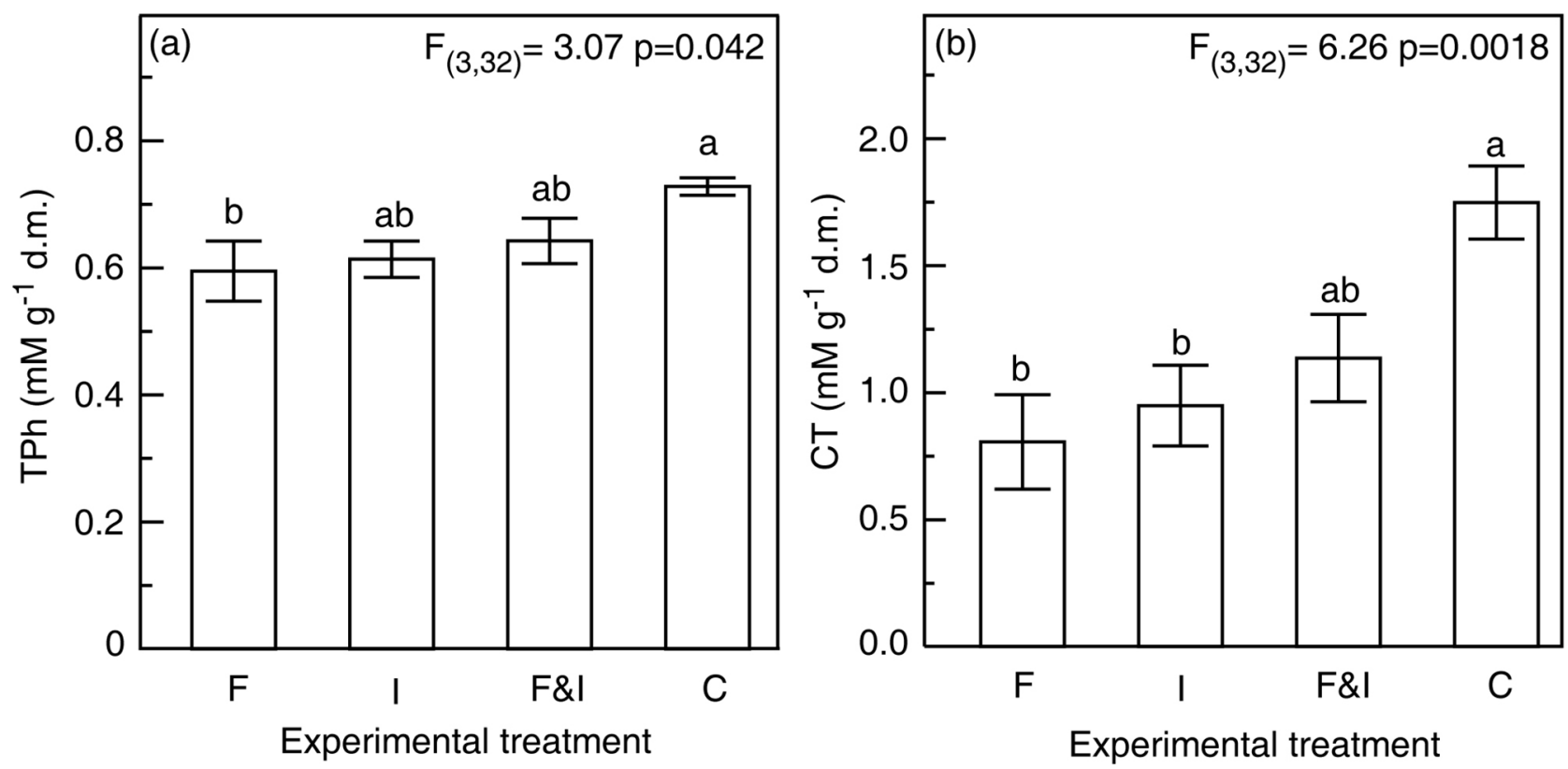

Fig 6. Mean, standard errors and ANOVA results for content of total soluble phenolic (TPh, in millimoles of chlorogenic acid per gram of dry matter) and condensed tannins (CT, in millimoles of catechin per gram of dry matter) in leaves of saplings from experimental treatments (description like in Figure 1). Means not connected by the same letter are significantly different (Tukey HSD)

stronger than that observed in saplings from the $\mathrm{F}$ variant and weaker, to some extent, from the I variant. Simultaneously, leaf damage dynamic on $\mathrm{F}$ and F\&I variants was weaker from that observed on the I variant. HCLM have three generations in the year and the intervals between those generations are slowing down the overall dynamic.

\section{Plant secondary metabolites}

Chemical analyses revealed the highest content of defence compounds in leaves of saplings from the $\mathrm{C}$ variant and lowest in F (Fig. 6). When the above mentioned diversity in leaf damage dynamics was taken into consideration, it is very likely that the plants investment to secondary metabolism in this particular case succeeded and resulted in lower leaf damage dynamic in saplings from the $\mathrm{C}$ variant in comparison with I treatment. Results indicate, that coexistence of both insect and fungi triggered higher CT levels in leaves (induced defence) in comparison with leaves of saplings where this biotic factor colonised plants separately (F and I treatments). The same was observed for the TPh content, but the differences are less distinct. Simultaneously, high levels of TPh and CT were also observed in saplings protected against pests. When comparing Figures 2 and 6 , the inverse proportion between TPh or CT and aSVI is very interesting. It is likely that investment in secondary compounds could be the reason for the lower increment.

\section{Stem volume increment modelling}

An attempt was made to explain how the features measured during the investigation (i.e. FLD, CPA, RDR, RDRday, maxDAcc, iSV) accounted for periodical and annual stem volume increment values. In the results of the stepwise analysis, three regression models were obtained - two of them with more than one predictor (Table 1). The volume increment of the first increment period (May to July) could be well explained $\left(\mathrm{R}^{2}=0.429\right.$, AIC $\left.=250.97\right)$ by $\mathrm{CPA}$ and day when leaves achieved full development (FLD):

$$
\mathrm{pSVI}_{\mathrm{V}-\mathrm{VII}}=170.71-1.206 \mathrm{FLD}+66.01 \mathrm{CPA}
$$

The volume increment of the second growth period, from August to the leaf abscission (LA) was explained only by the RDRday $\left(\mathrm{R}^{2}=0.284\right.$, $\mathrm{AIC}=164.16)$ :

$$
\mathrm{pSVI}_{\mathrm{VIII-LA}}=-1.26+0.0588 \mathrm{RDRday}
$$

The aSVI, sum of increments from two periods, was well explained by three variables $\left(\mathrm{R}^{2}=0.462\right.$, $\mathrm{AIC}=258.92$ ):

$\mathrm{aSVI}=161.97-1.20 \mathrm{FLD}+73.86 \mathrm{CPA}+0.103 \mathrm{RDRday}$

The equations obtained revealed that the first increment period was not influenced by leaf damage but assimilative organs quantity expressed by CPA and time, when leaves achieved final size (FLD). The poorest 
Table 1. ANOVA results for periodical ( $\mathrm{pSVI}_{\mathrm{V}-\mathrm{VII}}-$ from May to July, $\mathrm{pSVI}_{\mathrm{VIII-LA}}$ - from August to leaf abscission) and annual (aSVI) stem volume increment explained by variables chosen after forward stepwise analysis. FLD - day of year when plant leaves were fully developed; CPA crown projection area; RDRday - the day when RDR value of Richards model was achieved

\begin{tabular}{lcccrc}
\hline Feature & Variable & DF & Error DF & \multicolumn{1}{c}{$\mathrm{F}$} & $\mathrm{p}$ \\
\hline pSVI $_{\text {V-VII }}$ & FLD & 1 & 33 & 11.67 & 0.0017 \\
& CPA & 1 & 33 & 8.41 & 0.0066 \\
pSVI $_{\text {VIII-LA }}$ & RDRday & 1 & 34 & 13.51 & 0.0008 \\
aSVI & FLD & 1 & 32 & 9.67 & 0.0039 \\
& CPA & 1 & 32 & 8.79 & 0.0057 \\
& RDRday & 1 & 32 & 3.23 & 0.0818 \\
\hline
\end{tabular}

explained increment period, laid in late summer was affected by delay of achieved RDR. Hence, observed differences between experimental treatments (Fig. 2) in aSVI were probably affected by estimated foliage area (initial CPA), time when FLD occurred and by low damage in the first increment period when a greater part of the stem volume increment was indicated.

\section{Molecular analyses}

Identification of G. aesuli based on comparison of sequences with a reference sequence from the NCBI GenBank confirmed the identification of the pathogen.

\section{Discussion}

Differences were found in the content of defence compounds in leaves from saplings in applied experimental variants. The lowest content of TPh and CT was found when only horse chestnut leaf miner (HCLM) was feeding in leaves in keeping with the results of Oszmiański et al. (2014) where after colonisation by this insect, decreased content of some groups of phenolic compounds was observed. The plants responded similarly, in a variant with insecticide treatment, when only fungal infection was observed on leaves. In turn, in control plants where both insect and leaf blotch disease were co-existing induced synthesis of secondary metabolites was observed. In concordance with the phytohormonal theory (Lazebnik et al., 2014) it may be the effect of different pathways of phytohormones, i.e. jasmonic acid and salicylic acid that are involved when both insect and pathogen are colonising the leaf tissue separately or simultaneously (Thaler et al., 2002).

Tannins, including condensed, could play antibiotic roles and were found to have antifungal activity (Scalbert, 1991). It is likely that they are not playing an important role in insect-plant interaction in comparison with other secondary metabolites (Ayres et al., 1997). When considering the biochemical aspects of lepidopterans midgut it is worth emphasising that CT protein precipitation capacity reaction requires an acidic or neutral environment (Salminen \& Karonen, 2011) while in lepidopterans larva's it is alkaline (Terra et al., 1996). Taking into account Stygar et al. (2010) results about $C$. ohridella digestive enzymes activity it is very likely that the investigated insect is not affected by CT. Hence, the observed higher content of CT when C. ohridella and G. aesculi co-occur probably creates unfavourable conditions for development only for the latter. In turn, higher content of phenolic compounds from the procyanidins group in leaves of the red horse chestnut (A. $x$ carnea) in comparison to $A$. hippocastanum (Oszmiański et al., 2014) is not coinciding with less susceptibility of the former for leaf blotch disease (Pastirčáková et al., 2009). It should also be emphasised that biosynthesis of secondary metabolites could be restricted to particular tissue (Pichersky \& Gang, 2000) and investigated leaf mining insect feeds only in palisade mesophyll omitting the part of the leaf blade which is rich in tannins (Weryszko-Chmielewska \& Haratym, 2011). Leaf damage dynamics of saplings with both pests (control) in comparison with saplings where the plant was protected against the insect was slightly lower in the latter saplings (RDR, maxDAcc, Fig. $5)$. It is likely our results are opposite to that reported in Mouttet et al. (2013) where leaf mining insect feeding had a positive effect on leaf colonisation by fungal pathogen. Earlier infestation by aphids enabled fungal pathogens to spread more rapidly in De Zutter et al. (2017) study. The two studies previously mentioned gave results that were incompatible with the results of this study. This emphasises the variety of plant responses, especially when leaf miners are taken into account (Inbar et al., 1999; Kawazu et al., 2012).

The results of this study showed reduction in annul aboveground increment may be explained both by foliage loss dynamic and effect of synthesised defence metabolites. When growth was separated for two periods (Fig. 3), the increment from the first period was determined by amount of synthesised secondary metabolites rather than leaf damage, which was low at the time. It is likely that amount of assimilative organs loss affects growth of saplings like in Wiley et al. (2013). Furthermore, the leaf damage caused a slight decrease in stem volume increment when its dynamics took place later. It would be in consistence with Ericsson et al. (1980) where the degree of defoliation affected the ring width increment on the stem cross section. Salemaa and Jukola-Sulonen (1990) also found a relationship between defoliation and ring with increment as well as volume growth of the trunk. Artificial defoliated angiosperm Populus reacted similarly (Reichenbacker et 
al., 1996). In concordance with our results, time of defoliation event both with degree of defoliation is the reason of increment loss (Nykänen \& Koricheva, 2004). The crown projection area (Cole \& Lorimer, 1994) or exposed crown area (Wyckoff \& Clark, 2005) were employed to equations predicting tree growth along with other biometrical features. In this study defoliation affected stem volume increment and was explained by the time when the value of relative leaf damage rate (RDR) was achieved, CPA and time from full leaf development (FLD). Hence, CPA with quantified damage dynamics constitutes a good predictor when influence of defoliation on growth is under investigation. Johnson et al. (2015) found visual assessment of herbivory is faster and can be accurate and precise. Plant foliage quantity estimation expressed by CPA has one great advantage in comparison with the visual one - obtained data is in a continuous scale which allows for more powerful, statistical parametric tests. It also provides with certainty results that are not biased.

According to the hypotheses put forward in our study, A. hippocastanum response is different when insect feeding and colonisation by fungus is separated in comparison with coexistence of both pests (i). This plant response, expressed by content of phenolic compounds affected fungus, rather than insect and foliage damage dynamics was higher when the fungus colonised leaves and the plant was protected against the insect (ii). Finally, both factors: limitation in carbon source and investment to secondary metabolisms, affected plant aboveground woody tissue increment (iii). The observed differences between carbon allocation to secondary metabolism and growth is in concordance with the growth-defence trade-off theory (Huot et al., 2014). However, carbon "expensive" metabolites reduced fungal pathogen dynamics only slightly. From an ecological point of view, such investment may not be necessarily to provide better fitness of plants in their environment. Still, there is a lack of study dealing with more extensive direct plant-pathogenic fungus-insect interaction and influence of $G$. aesculi on ontogenesis of $C$. ohridella. It would be crucial for recognising this phenomenon, as overwintering, the last generation of insect, which colonised A. hippocastanum in spring could be affected by this interaction. Another question is about the influence of sun exposure which probably affected plants, as solar UV-B radiation is highly involved in the elicitation of phenolic compounds due to use of jasmonate-dependent and -independent pathways (Demkura et al., 2010). Hence, light conditions should be considered as factors coinciding in interaction of insect-pathogen-plant interactions, as the response could be not specific only to pests in future investigations.

\section{Acknowledgments}

We are indebted to Christopher Bates from Bangor University for proof reading of the manuscript. The research was financially supported by the National Science Center, Poland (grant no. 2012/07/B/ NZ9/01315).

\section{References}

Augustin S, Guichard S, Heitland W, Freise J, Svatoš A \& Gilbert M (2009) Monitoring and dispersal of the invading Gracillariidae Cameraria ohridella. Journal of Applied Entomology 133: 58-66. doi:10.1111/j.1439-0418.2008.01333.x.

Ayres MP, Clausen TP, MacLean Jr. SF, Redman AM \& Reichardt PB (1997) Diversity of Structure and Antiherbivore Activity in Condensed Tannins. Ecology 78: 1696-1712. doi:10.2307/2266094.

Bednarz B \& Scheffler M (2008) Wpływ żeru szrotówka kasztanowcowiaczka (Cameraria ohridella Deschka \& Dimic) na szerokość słojów rocznych kasztanowca białego (Aesculus hippocastanum L.). Sylwan 152: 53-66.

Bhatti I, Ozanne C \& Shaw P (2013) Parasitoids and parasitism rates of the horse chestnut leaf miner Cameraria ohridella Deschka and Dimić [Lepidoptera: Gracillariidae] across four sites in southwest London. Arboricultural Journal 35: 147-159. doi:10.1080/03071375.2013.813706.

Cole WG \& Lorimer CG (1994) Predicting tree growth from crown variables in managed northern hardwood stands. Forest Ecology and Management 67: 159-175. doi:10.1016/0378-1127(94)90014-0.

Demkura PV, Abdala G, Baldwin IT \& Ballare CL (2010) Jasmonate-dependent and -independent pathways mediate specific effects of solar ultraviolet $\mathrm{B}$ radiation on leaf phenolics and antiherbivore defense. Plant Physiology 152: 1084-1095. doi:10.1104/pp.109.148999.

Deschka G \& Dimić N (1986) Cameraria ohridella sp. n. (Lep., Lithocolletidae) aus Mazedonien, Jugoslawien. Acta entomologica Jugoslavica 22: 11-23.

Ericsson A, Larsson S \& Tenow O (1980) Effects of early and late season defoliation on growth and carbohydrate dynamics in scots pine. Journal of Applied Ecology 17: 747-769. doi:10.2307/2402653.

Franiel I, Woźnica P \& Orlik H (2014) Zaburzenia procesu kwitnienia i owocowania Aesculus hippocastanum L. jako efekt żerowania Cameraria ohridella Deschka \& Dimić. Sylwan 158: 41-48.

Gardes M \& Bruns TD (1993) ITS primers with enhanced specificity for basidiomycetes - application to the identification of mycorrhizae and rusts. Molecular Ecology 2: 113-118. doi:10.1111/j.1365294X.1993.tb00005.x. 
Gilbert M, Svatoš A, Lehmann M \& Bacher S (2003) Spatial patterns and infestation processes in the horse chestnut leafminer Cameraria ohridella: A tale of two cities. Entomologia Experimentalis et Applicata 107: 25-37. doi:10.1046/j.15707458.2003.00038.x.

Gregorczyk A (1998) Richards plant growth model. Journal of Agronomy and Crop Science 181: 243 247. doi:10.1111/j.1439-037X.1998.tb00424.x.

Hudson HJ (1987) Guignardia leaf blotch of horsechestnut. Transactions of the British Mycological Society 89: 400-401.

Huot B, Yao J, Montgomery BL \& He SY (2014) Growth-defense tradeoffs in plants: a balancing act to optimize fitness. Molecular Plant 7: 12671287. doi:10.1093/mp/ssu049.

Inbar M, Doostdar H, Leibee GL \& Mayer RT (1999) The role of plant rapidly induced responses in asymmetric interspecific interactions among insect herbivores. Journal of Chemical Ecology 25: 1961-1979. doi:10.1023/A:1020998219928.

Johnson G \& Schaal LA (1957) Accumulation of phenolic substances and ascorbic acid in potato tuber tissue upon injury and their possible role in disease resistance. American Potato Journal 34: 200-209. doi:10.1007/BF02854948.

Johnson MTJ, Bertrand JA \& Turcotte MM (2016) Precision and accuracy in quantifying herbivory. Ecological Entomology 41: 112-121. doi:10.1111/ een.12280.

Karolewski P \& Jagodziński AM (2013) Share of carbon in defense compounds against biotic factors in woody plants. Sylwan 157: 831-841.

Kawazu K, Mochizuki A, Sato Y, Sugeno W, Murata M, Seo S \& Mitsuhara I (2012) Different expression profiles of jasmonic acid and salicylic acid inducible genes in the tomato plant against herbivores with various feeding modes. Arthropod-Plant Interactions 6: 221-230. doi:10.1007/ s11829-011-9174-z.

Kessler A \& Baldwin IT (2002) Plant responses to insect herbivory: the emerging molecular analysis. Annual Review of Plant Biology 53: 299-328. doi:10.1146/annurev.arplant.53.100301.135207.

Lazebnik J, Frago E, Dicke M \& van Loon JJA (2014) Phytohormone mediation of interactions between herbivores and plant pathogens. Journal of Chemical Ecology 40: 730-741. doi:10.1007/s10886014-0480-7.

Mithöfer A \& Boland W (2012) Plant defense against herbivores: Chemical aspects. Annual Review of Plant Biology 63: 431-450. doi:10.1146/annurev-arplant-042110-103854.

Mouttet R, Kaplan I, Bearez P, Amiens-Desneux E \& Desneux N (2013) Spatiotemporal patterns of induced resistance and susceptibility linking di- verse plant parasites. Oecologia 173: 1379-1386. doi:10.1007/s00442-013-2716-6.

Neilson EH, Goodger JQD, Woodrow IE \& Møller BL (2013) Plant chemical defense: at what cost? Trends in Plant Science 18: 250-258. doi:10.1016/j.tplants.2013.01.001.

Nykänen H \& Koricheva J (2004) Damage-induced changes in woody plants and their effects on insect herbivore performance: a meta-analysis. Oikos 104: 247-268. doi:10.1111/j.00301299.2004.12768.x.

Oszmiański J, Kalisz S \& Wojdyło A (2014) The content of phenolic compounds in leaf tissues of white (Aesculus hippocastanum L.) and red horse chestnut (Aesculus carea H.) colonized by the horse chestnut leaf miner (Cameraria ohridella Deschka \& Dimić). Molecules 19: 14625-14636. doi:10.3390/molecules190914625.

Pastirčáková K, Pastirčák M, Celar F \& Shin H-D (2009) Guignardia aesculi on species of Aesculus: new records from Europe and Asia. Mycotaxon 108: 287-296.

Percival GC, Barrow I, Noviss K, Keary I \& Pennington P (2011) The impact of horse chestnut leaf miner (Cameraria ohridella Deschka and Dimic; HCLM) on vitality, growth and reproduction of Aesculus hippocastanum L. Urban Forestry \& Urban Greening 10: 11-17. doi:10.1016/j.ufug.2010.11.003.

Pichersky E \& Gang DR (2000) Genetics and biochemistry of secondary metabolites in plants: an evolutionary perspective. Trends in Plant Science 5: 439-445. doi:10.1016/S1360-1385(00)017416.

Price ML, Van Scoyoc S \& Butler LG (1978) A critical evaluation of the vanillin reaction as an assay for tannin in sorghum grain. Journal of Agricultural and Food Chemistry 26: 1214-1218. doi:10.1021/ jf60219a031.

Reichenbacker RR, Schultz RC \& Hart ER (1996) Artificial defoliation effect on Populus growth, biomass production, and total nonstructural carbohydrate concentration. Environmental Entomology 25: 632-642. doi:10.1093/ee/25.3.632.

Richards FJ (1959) A flexible growth function for empirical use. Journal of Experimental Botany 10: 290-300. doi:10.1093/jxb/10.2.290.

Salemaa M, Jukola-Sulonen EL (1990) Vitality rating of picea abies by defoliation class and other vigour indicators. Scandinavian Journal of Forest Research 5: 413-426. doi:10.1080/02827589009382624.

Salminen J-P \& Karonen M (2011) Chemical ecology of tannins and other phenolics: we need a change in approach. Functional Ecology 25: 325-338. doi:10.1111/j.1365-2435.2010.01826.x.

Scalbert A (1991) Antimicrobial properties of tannins. Phytochemistry 30: 3875-3883. doi:10.1016/0031-9422(91)83426-L. 
Singleton VL \& Rossi Jr. JA (1965) Colorimetry of total phenolics with phosphomolybdic-phosphotungstic acid reagents. American Journal of Enology and Viticulture 16: 144-158.

Stout MJ, Thaler JS \& Thomma BPHJ (2006) Plant-mediated interactions between pathogenic microorganisms and herbivorous arthropods. Annual Review of Entomology 51: 663-689. doi:10.1146/annurev.ento.51.110104.151117.

Strauss SY, Rudgers JA, Lau JA \& Irwin RE (2002) Direct and ecological costs of resistance to herbivory. Trends in Ecology \& Evolution 17: 278285. doi:10.1016/S0169-5347(02)02483-7.

Stygar D, Dolezych B, Nakonieczny M, Migula P, Michalczyk K \& Zaak M (2010) Digestive enzymes activity in larvae of Cameraria ohridella (Lepidoptera: Gracillariidae). Comptes Rendus Biologies 333: 725-735. doi:10.1016/j.crvi.2010.08.004.

Terra WR, Ferreira C \& Baker JE (1996) Compartmentalization of digestion: Biology of the insect midgut (ed. by MJ Lehane \& PF Billingsley) Chapman \& Hall, London, pp. 206-235.

Thaler JS, Fidantsef AL \& Bostock RM (2002) Antagonism between jasmonate- and salicylate-mediated induced plant resistance: effects of concentration and timing of elicitation on defense-related proteins, herbivore, and pathogen performance in tomato. Journal of Chemical Ecology 28: 11311159. doi:10.1023/A:1016225515936.

Thalmann C, Freise J, Heitland W \& Bacher S (2003) Effects of defoliation by horse chestnut leafminer (Cameraria ohridella) on reproduction in Aesculus hippocastanum. Trees 17: 383-388. doi:10.1007/s00468-003-0249-z.

Thomma BP, Penninckx IA, Broekaert WF \& Cammue BP (2001) The complexity of disease signaling in
Arabidopsis. Current Opinion in Immunology 13: 63-68. doi:10.1016/S0952-7915(00)00183-7.

Tomiczek C \& Krehan H (1998) The horsechesnut leafmining moth (Cameraria Ohridella): A new pest in Central Europe. Journal of Arboriculture 24: 144-148.

Weryszko-Chmielewska E \& Haratym W (2011) Changes in leaf tissues of common horse chestnut (Aesculus hippocastanum L.) colonised by the horse-chestnut leaf miner (Cameraria ochridella Deschka\&Dimić). Acta Agrobotanica 64: 11-22.

White TJ, Bruns T, Lee S \& Taylor J (1990) Amplification and direct sequencing of fungal ribosomal RNA genes for phylogenetics: PCR Protocols: A Guide to methods and applications (ed. by MA Innis, DH Gelfand, JJ Sninsky \& TJ White) Academic Press, New York, pp. 315-322.

Wiley E, Huepenbecker S, Casper BB \& Helliker BR (2013) The effects of defoliation on carbon allocation: can carbon limitation reduce growth in favour of storage? Tree Physiology 33: 1216-1228. doi:10.1093/treephys/tpt093.

Wyckoff PH \& Clark JS (2005) Tree growth prediction using size and exposed crown area. Canadian Journal of Forest Research 35: 13-20. doi:10.1139/x04-142.

De Zutter N, Audenaert K, Ameye M, De Boevre M, De Saeger S, Haesaert G \& Smagghe G (2017) The plant response induced in wheat ears by a combined attack of Sitobion avenae aphids and Fusarium graminearum boosts fungal infection and deoxynivalenol production. Molecular Plant Pathology 18: 98-109. doi:10.1111/mpp.12386. 